\title{
IMPLEMENTASI BALANCED SCORECARD SEBAGAI ALAT PENGUKUR KINERJA PADA RUMAH SAKIT BHAYANGKARA POLDA BENGKULU
}

\author{
Antoni Sibarani \\ Nani Halima Zahara \\ Program Studi Manajemen \\ Fakultas Ekonomi Universitas Dehasen Bengkulu
}

\begin{abstract}
ABSTRAK
Antoni Sibarani, Nani Halima Zahara; Implementasi Balanced Scorecard sebagai alat pengukur kinerja pada Rumah Sakit Bhayangkara POLDA Bengkulu. Penelitian ini bertujuan untuk mengetahui bagaimana kinerja rumah sakit apabila menggunakan Balanced Scorecard. Dengan menggunakan Balanced Scorecard diharapkan rumah sakit dapat mengembangkan aspek keuangan dan non keuangan dalam melakukan penilaian kinerja, sehingga nantinya diharapkan bahwa rumah sakit mampu menjadi institusi yang dapat memberikan kepuasan kepada para konsumen, karyawan yang berkomitmen tinggi dan kemudian akan menghasilkan surplus yang memadai. Penelitian dilakukan dengan mengambil data selama 2 tahun, yaitu tahun 2011-2012, menggunakan analisis komparatif dimana peneliti melakukan evaluasi kinerja rumah sakit antar periode kemudian membandingkan dengan target yang sebelumnya telah ditetapkan dan kemudian diberi skor sesuai dengan kriteria. Data diperoleh melalui studi pustaka, data sekunder Rumah Sakit Bhayangkara POLDA Bengkulu pengukuran kinerja dilihat dari 4 perspektif yaitu, keuangan, pelanggan, proses bisnis internal, dan pembelajaran dan pertumbuhan. Dari hasil penelitian dengan menggunakan konsep Balanced Scorecard dapat ditarik kesimpulan hasil pengukuran kinerja secara keseluruhan dari Rumah Sakit Bhayangkara POLDA Bengkulu terdapat pada daerah baik, dengan skor total 0,57. Artinya, Kinerja Rumah Sakit Bhayangkara POLDA Bengkulu sudah baik apabila diukur dengan pendekatan Balanced Scorecard.
\end{abstract}

\begin{abstract}
Antoni Sibarani, Nani Halima Zahara; The Implemetation of Balanced Scorecard as a tool of measuring performance in Bayangkara Polda Hospital of Bengkulu. This research aims to determine how the performance of Hospital by using the "Balanced Scorecard". The use of "Balanced Scorecard" is expected that hospital can improve/develop the financial and nonfinancial performances for measuring the evaluation activity, so it will provide the satisfication to the customers, employers, and also sufficient surplus. This study took the data within the lastest two years (2011 to 2012) by using a comparative analysis, the researcher evaluated the performances of hospital between several periods and then compare with the pervious targets which have been set and scored according to the criteria. The data obstained from some sources; the evaluations of Hospital Bhayangkara within four perspectives; financial, customers, internal bussiness processes, and learning and growth. From the results of the study the concept of the Balanced Scorecard measurement can be deduced from the overall performance of Bhayangkara Hospital Bengkulu is 0.57. This study showed that Hospital Bhayangkara getting better if it is measured with the Balanced Scorecard approach.
\end{abstract}

\section{Kata kunci: Kinerja, Balanced Scorecard, Rumah Sakit}

\section{PENDAHULUAN}

Saat ini masih banyak Rumah Sakit yang mengukur kinerjanya hanya berdasarkan pada tolak ukur keuangannya saja. Padahal dalam menghadapi lingkungan bisnis yang semakin 
kompleks seperti saat ini, pengukuran kinerja yang hanya berdasar pada tolak ukur keuangan sudah tidak lagi memadai karena memnpunyai banyak kelemahan, antara lain seperti:

Pemakaian kinerja keuangan sebagai satu-satunya penentu kinerja Rumah Sakit bisa mendorong kepala Rumah Sakit untuk mengambil tindakan jangka pendek dengan mengorbankan kepentingan jangka panjang. Misalnya, untuk menaikkan profit atau ROI (Return on investment), seorang kepala Rumah Sakit bisa saja mengurangi anggaran untuk pengembangan atau pelatihan bagi karyawan, termasuk investasi dalam sistem teknologi untuk kepentingan Rumah Sakit dimasa depan. Dalam jangka pendek kinerja keuangan meningkat, namun dalam jangka panjang akan menurun.

Diabaikannya aspek pengukuran non-finansial pada umumnya, baik dari sumber internal maupun eksternal akan memberikan suatu pandangan yang keliru bagi kepala Rumah Sakit mengenai Rumah Sakit di masa sekarang terlebih lagi di masa datang. Kinerja Keuangan hanya bertumpu pada kinerja masa lalu dan kurang mampu sepenuhnya untuk menuntun Rumah Sakit kearah tujuan Rumah Sakit yang lebih baik.

Setiap Rumah Sakit, harus menginvestasikan dan mengelola aset intelektual mereka. Hal ini disebabkan karena aset intelektual memampukan Rumah Sakit Bhayangkara POLDA Bengkulu untuk:

a. Membangun hubungan baik dengan konsumen yang akan memelihara kesetiaan dari konsumen yang ada dan memungkinkan segmen konsumen dan area pasar yang baru dapat dilayani dengan efektif dan efisian.

b. Memperkenalkan jasa inovatif yang diinginkan oleh target segmen konsumen.

c. Memproduksi jasa yang berkualitas tinggi pada tingkat biaya yang rendah dan dengan waktu rawat yang singkat.

d. Mengerahkan kemampuan dan motivasi karyawan untuk melakukan peningkatan secara terus menerus dalam pelayanan kapabilitas proses, kualitas, dan waktu respon.

Kesuksesan Rumah Sakit tidak dapat dimotivasi atau diukur dalam jangka pendek dengan model manajemen keuangan tradisional saja. Balanced Scorecard merupakan kerangka kerja baru untuk mengintegrasikan ukuran yang diperoleh dari strategi. Dengan tetap mempertahankan ukuran keuangan sebelumnya, Balanced Scorecard memperkenalkan item tambahan yang meliputi konsumen, proses bisnis internal, dan perspektif pembelajaran dan pertumbuhan.

Balanced Scorecard lebih dari sekedar sistem pengukuran. Rumah Sakit dapat menggunakan Balanced Scorecard sebagai dasar untuk mengatur kerangka kerja untuk proses manajemen mereka. Rumah Sakit dapat membangun Balanced Scorecard mula-mula dengan tujuan yang terbatas, misalnya untuk mendapatkan klarifikasi dan fokus terhadap strategik pada Rumah Sakit Bhayangkara POLDA Bengkulu, lalu mengkomunikasi strategik tersebut kepada seluruh anggota Rumah Sakit. Dengan kata lain, Balanced scorecard mendidik manajemen dan organisasi pada umumnya untuk memandang Rumah Sakit dari empat perspektif yaitu keuangan, pelanggan, proses bisnis internal, dan perspektif pembelajaran dan pertumbuhan yang menghubungkan pengendalian operasional jangka pendek ke dalam visi dan strategi bisnis jangka panjang.

Seperti yang telah disebutkan diatas, Balanced Scorecard mengklarifikasi pengukuran kinerja ke dalam 4 perspektif yaitu, keuangan, pelanggan, proses bisnis internal, dan pembelajaran dan pertumbuhan. Keempat perspektif ini menawarkan suatu keseimbangan antara tujuan jangka pendek dan tujuan jangka panjang, yaitu hasil yang diinginkan, pemicu kinerja, dan tolak ukur kinerja.

Rumah Sakit Bhayangkara POLDA Bengkulu merupakan salah satu dari sekian banyak Rumah Sakit yang ada di Provinsi Bengkulu khususnya di kota Bengkulu. Rumah Sakit Bhanyangkara POLDA Bengkulu ini berlokasi di Jalan Veteran No 2 Kelurahan Jitra Kecamatan Teluk Segara Kota Bengkulu. Selama ini Rumah Sakit Bhayangkara POLDA Bengkulu mengukur kinerja dengan melakukan analisis terhadap laporan keuangannya dan membandingkannya dengan hasil yang diperoleh pada periode sebelumnya. 


\section{TINJAUAN LITERATUR \\ Pengertian Kinerja}

Menurut Mangkunegara (2005:59) pengertian kinerja adalah hasil kerja secara kualitas dan kuantitas yang dicapai oleh pegawai dalam melaksanakan tugasnya sesuai dengan tanggung jawab yang diberikan.

Kinerja adalah hasil kerja yang dapat dicapai oleh seseorang atau kelompok orang dalam suatu perrusahaan sesuai dengan wewenang dan tanggung jawab masing-masing dalam upaya pencapaian tujuan Rumah Sakit secara legal, tidak melanggar hukum dan tidak bertentangan dengan moral atau etika.

Menurut D.Stout (dalam Yuwono,2002:65) mengatakan bahwa pengukuran kinerja merupakan proses mencatat dan mengukur pencapaian pelaksanaan kegiatan dalam arah pencapaian misi melalui hasil-hasil yang ditampilkan berupa produk, jasa ataupun suatu proses. Mencatat dan mengukur pencapaian kegiatan dalam arah pencapaian visi dan misi organisasi.

Pengukuran kinerja Rumah Sakit yang hanya ditekankan pada sudut pandang keuangan, sering menghilangkan sudut pandang lain yang tidak kalah pentingnya sehingga akan meninggalkan suatu kesenjangan antara pengembang suatu strategi dan implikasinya.

\section{Tujuan dan Manfaat Kinerja}

Pengukuran kinerja mempunyai tugas pokok yaitu untuk memotivasi karyawan dalam pencapaian sasaran organisasi dengan tetap mematuhi standar perilaku yang telah ditetapkan sebelumnya, agar membuahkan tindakan dan hasil yang diinginkan (Mardiasmo,2002:122).

Secara umum, tujuan pengukuran kinerja adalah sebagai berikut :

1. Mengkomunikasikan strategi secara lebih mantap.

2. Mengukur kerja finansial dan nonfinansial secara berimbang, sehingga dapat ditelusuri perkembangan pencapaian strategi.

3. Mengakomodasi pemahaman kepentingan manajer level menengah dan bawah serta memotivasi untuk mencapai goal congruence.

4. Alat untuk mencapai kepuasaan berdasarkan pendekatan individual dan kemampuan kolektif rasional.

Menurut Uhum (2009:22) Manfaat pengukuran kinerja baik untuk internal maupun eksternal organisasi:

1. Memastikan pemahaman para pelaksana akan ukuran yang digunakan untuk pencapaian kinerja.

2. Memastikan tercapainya rencana kinerja yang telah disepakati.

3. Memantau dan mengevaluasi pelaksanaan kinerja dan membandingkannya dengan rencana kerja serta melakukan tindakan untuk memperbaiki kinerja.

4. Memberikan penghargaan dan hukuman yang obyektif atas prestasi pelaksana yang telah diukur sesuai dengan sistem pengukuran kinerja yang telah disepakati.

5. Menjadi alat komunikasi antara bawahan dan pimpinan dalam upaya memperbaiki kinerja organisasi.

6. Mengidentifikasi apakah kepuasaan pelanggan sudah terpenuhi.

7. Membantu memahami proses kegiatan instansi kepolisian

8. Memastikan bahwa pengambilan keputusan dilakukan secara obyektif.

9. Menunjukkan peningkatan yang telah perlu dilakukan.

10. Mengungkapkan permasalahan yang terjadi.

\section{Pengertian Balanced Scorecard}

Balanced scorecard merupakan suatu sistem manajemen, pengukuran, dan pengendalian yang secara cepat, tepat, dan komprehensif dapat memberikan pemahaman kepada manajer tentang kemampuan bisnis Rumah Sakit. Pengukuran kinerja dengan Balanced scorecard 
memandang unit bisnis dari empat perspektif, yaitu perspektif keuangan, pelanggan, proses bisnis dalam Rumah Sakit, serta proses pembelajaran dan pertumbuhan.

Menurut Mulyadi (2001:17)," Balanced scorecard adalah suatu alat untuk mengukur secara komprehensif dengan pola manajemen strategis". Sedangkan menurut J.Blohcer (2000:21), Pengertian Balanced scorecard adalah"Laporan akuntansi yang meliputi empat aspek keberhasilan kritis Rumah Sakit: kinerja keuangan, kepuasaan pelanggan, proses bisnis internal, inovasi dan pembelajaran".

Selain itu, Balanced scorecard juga memberikan kerangka berpikir untuk menjabarkan strategik Rumah Sakit ke dalam segi operasional. Sebelum Balanced scorecard, pada saat penyusunan (building) Balanced scorecard, terlebih dulu dijabarkan dengan jelas visi, misi, dan strategi Rumah Sakit dari top-management Rumah Sakit, karena hal ini menentukkan proses berikutnya berupa transaksi strategis kegiatan operasional dengan Balanced scorecard, tujuan suatu unit usaha tidak hanya dinyatakan dalam suatu ukuran keuangan saja, melainkan dijabarkan lebih lanjut kedalam pengukuran bagaimana unit usaha tersebut menciptakan nilai terhadap pelanggan yang ada sekarang dan masa datang, dan bagaimana unit usaha tersebut harus meningkatkan kemampuan internalnya termasuk investasi pada manusia, sistem, dan prosedur yang dibutuhkan untuk memperoleh kinerja yang lebih baik di masa mendatang. Melalui Balanced scorecard diharapkan bahwa pengukuran kinerja finansial dan non finansial dapat menjadi bagian dari sistem informasi bagi seluruh pegawai dan tingkatan dalam organisasi

\section{Keunggulan Balanced Scorecard}

Balanced Scorecard memiliki keunggulan yang menjadikan sistem manajemen strategik saat ini berbeda secara signifikan dengan sistem manajemen strategik dalam manajemen tradisional (Mulyadi,2001). Manajemen strategik tradisional hanya berfokus ke sasaran-sasaran yang bersifat keuangan, sedangkan sistem manajemen strategik kontemporer mencakup perspektif yang luas yaitu keuangan, pelanggan, proses bisnis internal, serta pembelajaran dan pertumbuhan.

Selain itu berbagai sasaran strategik yang dirumuskan dalam sistem manajemen strategik tradisional tidak koheren satu dengan lainnya, sedangkan berbagai sasaran strategik dalam sistem manajemen strategik kontemporer dirumuskan secara koheren.

Di samping itu, Balanced Scorecard menjadikan sistem manajemen strategic kontemporer memiliki karakteristik yang tidak dimiliki oleh sistem manajemen strategik tradisional, yaitu dalam karakteristik keterukuran dan keseimbangan.

Menurut Mulyadi (2001), keunggulan pendekatan Balanced Scorecard dalam sistem perencanaan strategik adalah mampu menghasilkan rencana strategik yang memiliki karakteristik sebagai berikut:

1. Komprehensif

Balanced Scorecard menambahkan perspektif yang ada dalam perencanaan strategik, dari yang sebelumnya hanya pada perspektif keuangan, meluas ke tiga perspektif yang lain, yaitu : pelanggan, proses bisnis internal, serta pembelajaran danpertumbuhan. Perluasan perspektif rencana strategik ke perspektif nonkeuangan tersebut menghasilkan manfaat sebagai berikut:

a. Menjanjikan kinerja keuangan yang berlipat ganda dan berjangka panjang,

b. Memampukan Rumah Sakit untuk memasuki lingkungan bisnis yang kompleks.

2. Koheren

Balanced Scorecard mewajibkan personel untuk membangun hubungan sebab akibat di antara berbagai sasaran strategik yang dihasilkan dalam perencanaan strategik. Setiap sasaran strategik yang ditetapkan dalam perspektif nonkeuangan harus mempunyai hubungan kausal dengan sasaran keuangan, baik secara langsung maupun tidak langsung.

Dengan demikian, kekoherenan sasaran strategik yang dihasilkan dalam sistem perencanaan strategik memotivasi personel untuk bertanggung jawab dalam mencari 
inisiatif strategik yang bermanfaat untuk menghasilkan kinerja keuangan. Sistem perencanaan strategik yang menghasilkan sasaran strategik yang koheren akan menjanjikan pelipat gandaan kinerja keuangan berjangka panjang, karena personel dimotivasi untuk mencari inisiatif strategik yang mempunyai manfaat bagi perwujudan sasaran strategik di perspektif keuangan, pelanggan, proses bisnis internal, pembelajaran dan pertumbuhan. Kekoherenan sasaran strategik yang menjanjikan pelipat gandaan kinerja keuangan sangat dibutuhkan oleh Rumah Sakit untuk memasuki lingkungan bisnis yang kompetitif.imbang

Keseimbangan sasaran strategik yang dihasilkan oleh sistem perencanaan strategik penting untuk menghasilkan kinerja keuangan berjangka panjang. Jadi perlu diperlihatkan garis keseimbangan yang harus diusahakan dalam menetapkan sasaransasaran strategik di keempat perspektif.

3. Terukur

Keterukuran sasaran strategik yang dihasilkan oleh sistem perencanaan strategik menjanjikan ketercapaian berbagai sasaran strategik yang dihasilkan oleh sistem tersebut. Semua sasaran strategik ditentukan oleh ukurannya, baik untuk sasaran strategik di perspektif keuangan maupun sasaran strategik di perspektif nonkeuangan.

Dengan Balanced Scorecard, sasaran-sasaran strategik yang sulit diukur, seperti sasaran-sasaran strategik di perspektif nonkeuangan, ditentukan ukurannya agar dapat dikelola, sehingga dapat diwujudkan. Dengan demikian keterukuran sasaran-sasaran strategik di perspektif nonkeuangan tersebut menjanjikan perwujudan berbagai sasaran strategik nonkeuangan, sehingga kinerja keuangan dapat berlipat ganda dan berjangka panjang.

\section{Perspektif Balance Scorecard}

Perspektif Balanced scorecard terdiri dari :

1. Perspektif Keuangan

Pengukuran kinerja keuangan akan menunjukkan apakah perencanaan dan pelaksanaan strategi memberikan perbaikan yang mendasar bagi keuntungan Rumah Sakit. Perbaikan-perbaikan ini tercermin dalam sasaran yang secara khusus berhubungan dengan keuntungan yang terukur dan pertumbuhan Rumah Sakit itu sendiri.

Menurut Mardiasmo (2002:22) yang menjadi tolak ukur dalam perspektif keuangan :

a. Profit Margin (Return on Sales)

Rasio profit margin (Return on Sales) digunakan Rumah Sakit Bhayangkara POLDA Bengkulu untuk menilai profitabilitas, sekaligus kemampuan manajemen Rumah Sakit Bhayangkara POLDA Bengkulu menekan biaya operasional. Rasio ini dihitung dengan membandingkan laba sesudah pajak dengan jumlah hasil penjualan yang diperoleh selama masa tertentu.

b. Gross Profit Margin

Rasio Gross Profit Margin memberikan indikasi tentang tingkat efisiensi operasi bisnis Rumah Sakit Bhayangkara POLDA Bengkulu. Apabila persentase gross profit margin rendah dapat diperkirakan bagian produksi dan/atau pembelian tidak bekerja secara efisien.

c. Return on Assets

Return on Assets atau sering disebut return on investment merupakan rasio keuangan yang digunakan untuk mengukur profitabilitas Rumah Sakit secara keseluruhan. Rasio keuangan ini juga memberikan gambaran tentang tingkat kemampuan manajemen Rumah Sakit Bhayangkara POLDA Bengkulu mengelola dana Rumah Sakitnya. Rasio profitabilitas ini memperbandingkan jumlah keuntungan yang diperoleh Rumah Sakit selama masa tertentu dengan dana yang ditanam dalam Rumah Sakit.

d. Return on Equity 
Return on Equity merupakan rasio yang digunakan pemilik Rumah Sakit untuk mengetahui tingkat profibilitas modal yang mereka tanamkan dalam Rumah Sakit Bhayangkara POLDA Bengkulu.

\section{Perspektif Pelanggan}

Perspektif ini merupakan leading indicator jadi jika pelanggan tidak puas mereka akan mencari produsen lain yang sesuai dengan kebutuhan mereka. Kinerja yang buruk dari perspektif ini akan menurunkan jumlah pelanggan di masa depan meskipun saat ini kinerja keuangan terlihat baik.

Sebelum tolak ukur atau indikator kinerja pelanggan diterapkan, Kaplan dan Norton (2000:55) menyarankan agar Rumah Sakit menerapkan terlebih dahulu yaitu :

a. Pangsa pasar : Penentuan segmen pasien yang akan menjadi target atau pelanggannya.

b. Kepuasaan pelanggan : Penampilan fisik dan mutu layanan yang diberikan oleh penyedia layanan.

c. Kemampuan mempertahankan pelanggan lama : Penampilan fasilitas pelayanan yang lebih ditingkatkan.

d. Kemampuan menarik pelanggan baru : Citra dan reputasi Rumah Sakit beserta pelayanannya sangat penting dimata masyarakat konsumen.

e. Kemampuan memperoleh pelanggan yang menguntungkan : Citra dan reputasi Rumah Sakit menggambarkan faktor-faktor intangible yang menarik seseorang konsumen untuk berhubungan dengan Rumah Sakit Bhayangkara POLDA Bengkulu.

Sebagai bahan ukur tolak ukur perspektif pelanggan adalah dengan melakukan perhitungan kuisioner terhadap indikator-indikator berikut ini:

1. Respon jawaban telepon

2. Tatakrama staff Rumah Sakit Bhayangkara POLDA Bengkulu saat menelepon

3. Waktu tunggu pelayanan lewat telepon

4. Penyambungan telepon pada orang yang tepat

5. Pelayanan staff penerima telepon secara keseluruhan

6. Pelayanan dan penanganan keluhan pasien

7. Waktu penyelesaian keluhan pasien

8. Pemenuhan schedule yang telah disepakati

9. Penjelasan yang diberikan tenaga teknis di lapangan

10. Keahlian tenaga teknis dalam menyelesaikan problem dilapangan

11. Profesionalisme dan pengetahuan tenaga teknis

12. Pelayanan yang diberikan pada Rumah Sakit Bhayangkara jika dibandingkan dengan Rumah Sakit lainnya

13. Tarif dan jasa yang ditawarkan

14. Pelayanan yang diberikan secara keseluruhan.

3. Perspektif Proses Bisnis Internal

Dalam perspektif ini memungkinkan kepala Rumah Sakit Bhayangkara POLDA Bengkulu untuk mengetahui seberapa baik bisnis mereka berjalan dan apakah produk dan atau jasa mereka sesuai dengan spesifikasi pasien. Perspektif ini harus didesain dengan hatihati oleh mereka yang paling mengetahui misi Rumah Sakit Bhayangkara POLDA Bengkulu yang mungkin tidak dapat dilakukan oleh Rumah Sakit luar.

Kaplan dan Norton (2000:57) perbedaan perspektif bisnis internal antara pendekatan tradisional dan pendekatan Balanced Scorecard adalah:

1. Pendekatan tradisional berusaha untuk mengawasi dan memperbaiki proses bisnis yang sudah ada sekarang. Sebaliknya, Balanced Scorecard melakukan pendekatan atau berusaha untuk mengenali semua proses yangdiperlukan untuk menunjang keberhasilan strategi Rumah Sakit, meskipun proses-proses tersebut belum dilaksanakan.

2. Dalam pendekatan tradisional, sistem pengukuran kinerja hanya dipusatkan bagaimana cara menyampaikan barang dan jasa. Sedangkan dalam pendekatan Balanced Scorecard, proses inovasi dimasukkan dalam perspektif proses bisnis internal. 
Kaplan dan Norton (2000:58) membagi proses bisnis internal kedalam : inovasi, operasi, dan layanan purna jual.

1. Proses inovasi

Proses ini, unit bisnis menggali pemahaman tentang kebutuhan laten dari pelanggan dan menciptakan produk dan jasa yang mereka butuhkan. Proses inovasi dalam Rumah Sakit biasanya dilakukan oleh bagian perencanaan sehingga setiap keputusan pengeluaran suatu perencanaan telah memenuhi syarat-syarat yang dapat diterapkan pada Rumah Sakit, sehingga sangat penting dalam menentukan kesuksesan Rumah Sakit Bhayangkara POLDA Bengkulu, terutama untuk jangka panjang.

2. Proses Operasi

Proses operasi adalah proses untuk membuat dan menyampaikan produk/jasa. Aktivitas di dalam proses operasi terbagi ke dalam dua bagian :

1) Proses pelayanan pada pasien.

2) Proses penyampaian jasa kepada pasien. Pengukuran kinerja yang terkait dalam proses operasi dikelompokkan pada: waktu, pelayanan dan biaya. Kaplan dan Norton (2000:58)

3. Proses Pelayanan Purna Jual

Proses ini merupakan jasa pelayanan pada pasien setelah penjualan produk/jasa dilakukan. Aktivitas yang terjadi dalam tahapan ini, misalnya penanganan pasien dan penjualan obat kepada pasien serta pemprosesan pembayaran pada pasien. Rumah Sakit dapat mengukur apakah upayanya dalam pelayanan purna jual ini telah memenuhi harapan pelanggan, dengan menggunakan tolak ukur yangbersifat kualitas, biaya dan waktu seperti yang dilakukan dalam proses operasi. Untuk siklus waktu, Rumah Sakit dapat menggunakan pengukuran waktu rawat dari saat keluhan pasien diterima hingga keluhan pasien tersebut diselesaikan.

Kaplan dan Norton (2000:60) bahan tolak ukur terhadap perspektif bisnis internal adalah melalui evaluasi proses terhadap wawancara dengan pihak manajemen dari Rumah Sakit Bhayangkara POLDA Bengkulu mengenai ketiga indikator di atas yaitu;

1. Proses Inovasi

2. Proses Operasi

3. Layanan Purna Jual

4. Perspektif Pembelajaran dan Pertumbuhan

Perspektif keempat pada Balanced Scorecard mengembangkan tujuan dan ukuran yang mendorong pembelajaran dan pertumbuhan Rumah Sakit. Proses pembelajaran dan pertumbuhan ini bersumber dari faktor sumber daya manusia, sistem, dan prosedur organisasi. Termasuk dalam perspektif ini adalah pelatihan pegawai dan budaya Rumah Sakit yang berhubungan dengan perbaikan individu dan organisasi. Dalam berbagai kasus, perspektif pembelajaran dan pertumbuhan merupakan fondasi keberhasilan bagi knowledgeworker organization dengan tetap memperhatikan faktor isitem organisasi.

Hasil dari pengukuran ketiga perspektif sebelumnya biasanya akan menunjukkan kesenjangan yang ada saat ini dengan yang dibutuhkan untuk mencapai kinerja yang diinginkan. Inilah mengapa, Rumah Sakit harus melakukan investasi di ketiga faktor tersebut untuk mendorong Rumah Sakit menjadi sebuah organisasi pembelajaran (learning organization).

Menurut Kaplan dan Norton "learning"lebih dari sekedar "training" karena pembelajaran meliputi pula proses "monitoring dan tutoring", seperti kemudahan dalam komunikasi di segenap pegawai yang memungkinkan mereka untuk siap membantu jika dibutuhkan. 


\section{Kerangka Analisis}

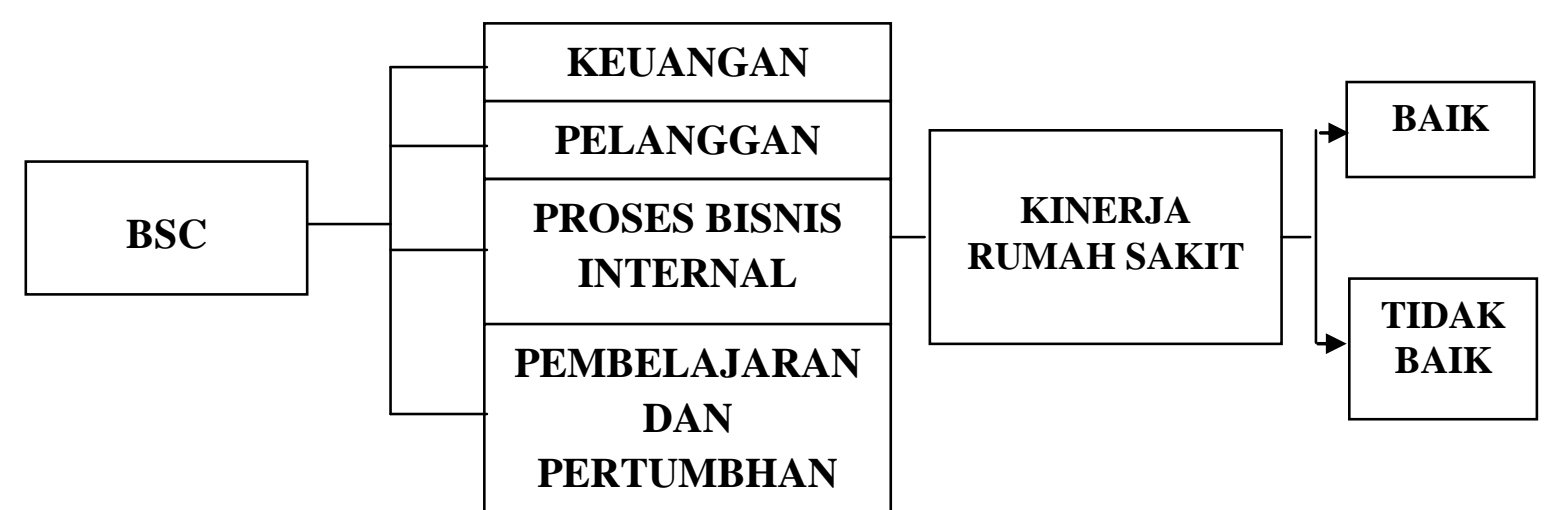

Gambar 1. Kerangka Analisis

\section{HASIL PENELITIAN DAN PEMBAHASAN Kinerja Perpektif Keuangan}

a. Rasio Ekonomi

Tabel 1. Rasio Ekonomis Rumah Sakit Bhayangkara POLDA Bengkulu selama tahun 2011-2012

\begin{tabular}{|l|l|l|c|}
\hline Tahun & Pengeluaran Institusi & \multicolumn{1}{l|}{ Anggaran yang ditetapkan } & Rasio Ekonomi \\
\hline 2011 & Rp.13.472.345.274 & Rp.14.310.786.862 & $94,14 \%$ \\
\hline 2012 & Rp.20.484.572.654 & Rp.22.064.770.989 & $92,84 \%$ \\
\hline
\end{tabular}

Sumber : Rumah Sakit Bhayangkara POLDA Bengkulu, 2013

Apabila melihat tabel diatas, secara umum kinerja perspektif keuangan Rumah Sakit Bhayangkara POLDA Bengkulu untuk rasio ini telah ekonomis. Karena kinerja keuangan institusi dikatakan ekonomis apabila diperoleh nilai kurang dari 100\% ( $\mathrm{x}<100 \%)$ untuk rasio ekonomi ini.

Dari tahun ketahun pengeluaran Rumah Sakit Bhayangkara POLDA Bengkulu tidak pernah melampaui anggaran yang ditetapkan atau dengan kata lain realisasi pengeluaran selalu lebih kecil bila dibandingkan dengan anggaran yang telah ditetapkan. Untuk tahun 2011 rasio ekonomi Rumah Sakit Bhayangkara POLDA Bengkulu sebesar 94,14\% hal ini mengindikasikan bahwa realisasi pengeluaran ditahun 2011 tidak melebihi anggaran yang ditetapkan. Ditahun 2012 rasio ekonomi Rumah Sakit Bhayangkara POLDA Bengkulu adalah sebesar 92,84\%, angka ini masih menunjukkan bahwa kinerja keuangan Rumah Sakit Bhayangkara POLDA Bengkulu masih ekonomis tetapi angka ini mengalami penurunan dari tahun sebelumnya, artinya ketercapaian target $100 \%$ realisasi atas pengeluaran masih belum optimal. Untuk itu, Rumah Sakit Bhayangkara POLDA Bengkulu perlu lebih memfokuskan diri dalam penyusunan anggaran sehingga anggaran yang telah ditetapkan tidak terlalu besar ataupun terlalu kecil sehingga dapat mencapai target $100 \%$ atau mendekati.

b. Rasio Efisiensi

Tabel 2. Rasio Efisiensi Rumah Sakit Bhayangkara POLDA Bengkulu selama tahun 2011-2012

\begin{tabular}{|l|l|c|c|}
\hline \multicolumn{1}{|c|}{ Tahun } & \multicolumn{1}{c|}{$\begin{array}{c}\text { Pengeluaran untuk } \\
\text { memperoleh pendapatan }\end{array}$} & Realisasi Pendapatan & $\begin{array}{c}\text { Rasio } \\
\text { Efisiensi }\end{array}$ \\
\hline 2011 & Rp. 11.907 .158 .275 & Rp. 14.371 .043 .224 & $82,86 \%$ \\
\hline 2012 & Rp. 18.307 .282 .584 & Rp. 21.536 .865 .164 & $85 \%$ \\
\hline
\end{tabular}

Sumber : Rumah Sakit Bhayangkara POLDA Bengkulu, 2013 
Penentuan pos pengeluaran tersebut didasarkan atas diskusi dengan bagian keuangan terkait dengan biaya yang harus dikeluarkan untuk memperoleh pendapatan. Dari tabel diatas, dari tahun 2011 dan 2012 rasio efisiensi Rumah Sakit Bhayangkara POLDA Bengkulu efisien. Karena kinerja keuangan institusi efisien apabila diperoleh nilai rasio efisiensi kurang dari $100 \%(\mathrm{x}<100 \%)$. Dari tabel diatas dapat dilihat bahwa rasio efisiensi ditahun 2011 adalah sebesar 82,86\% dan ditahun 2012 menjadi 85\% .Dari data tersebut, nilai rasio dapat dikatakan efisen karena diperoleh nilai rasio efisiensi kurang dari $100 \%(\mathrm{x}<100 \%)$.

c. Rasio Efektivitas

Tabel 3. Rasio Efektivitas Rumah Sakit Bhayangkara POLDA Bengkulu selama tahun 2011-2012

\begin{tabular}{|l|l|c|c|}
\hline \multicolumn{1}{|c}{ Tahun } & \multicolumn{1}{c}{ Realisasi Pendapatan } & \multicolumn{1}{c|}{ Target } & Rasio Efektivitas \\
\hline 2011 & Rp. 14.371 .043 .224 & Rp. 16.400 .000 .000 & $87,63 \%$ \\
\hline 2012 & Rp. 21.536 .865 .164 & Rp. 21.200 .000 .000 & $101,59 \%$ \\
\hline
\end{tabular}

Sumber : Rumah Sakit Bhayangkara POLDA Bengkulu, 2013

Apabila dilihat dari tabel diatas, peroleh pendapatan atau realisasi pendapatan bersifat fluktuatif. Di tahun 2011 rasio efektivitas berada di angka 87,63\%, sedangkan pada tahun 2011 rasio efektivitas sebesar 101,59\%.

Melihat dari penetapan anggaran dan realisasi untuk penentuan indicator efektivitas ini, rasio efektivitas untuk Rumah Sakit Bhayangkara POLDA Bengkulu ditahun 2011 masih belum efektif. Hal ini dapat dilihat dari rasio efektivitas yang jauh dari angka $100 \%$. Ditahun 2011 target pendapatan yang ditetapkan adalah Rp. 16.400.000.000, sedangkan realisasi pendapatannya hanya Rp. 14.371.043.224,-. Artinya terdapat selisih kurang atas realisasi pendapatan sebesar Rp. 2.028.956.776 dari anggaran. Meskipun begitu rasio efektivitas Rumah Sakit Bhayangkara POLDA Bengkulu ini dari tahun ketahun cenderung menunjukkan arah perbaikan, dimana pada tahun 2012 rasio efektivitas sebesar 101,59 \% artinya terdapat selisih lebih realisasi pendapatan sebesar Rp. 336.865.184 dari anggarannya. Hal ini menunjukkan bahwa kinerja keuangan Rumah Sakit Bhayangkara POLDA Bengkulu sudah efektif, terbukti dari tercapainya anggaran yang telah dibuat sebelumnya

\section{Kinerja Perpektif Pelanggan}

Dari data yang telah dikumpulkan dari hasil kuisioner kepada 35 orang pelanggan Rumah Sakit Bhayangkara POLDA Bengkulu dapat ditentukan interval kepuasan pasien Rumah Sakit Bhayangkara POLDA Bengkulu yang digunakan untuk mengetahui tingkat kepuasan pasien.

Penulis memberikan pertanyaan kepada pasien Rumah Sakit Bhayangkara POLDA dan pengukuran dalam menentukan jawaban pada penelitian ini yaitu menggunakan analisis skala likert. Adapun alternatif jawaban kuesioner dan pemberian skor adalah sebagai berikut:

a) Jawaban sangat puas akan diberi skor 5

b) Jawaban puas akan diberi skor 4

c) Jawaban ragu-ragu akan diberi skor 3

d) Jawaban tidak puas akan diberi skor 2

e) Jawaban sangat tidak puas akan diberi skor 1

Penetapan tingkat kepuasan pasien secara keseluruhan didasarkan pada skala yang digunakan untuk pengolahan data, yakni:

$\mathrm{IK}$ maks $=\mathrm{R} \times \mathrm{PP} \times \mathrm{EX}$ maks

$\mathrm{IK} \min \quad=\mathrm{R} \times \mathrm{PP} \times \mathrm{EX} \min$

Interval $\quad=(\mathrm{IK}$ maks $-\mathrm{IK} \mathrm{min})$

Sugiyono (2002: 80) 


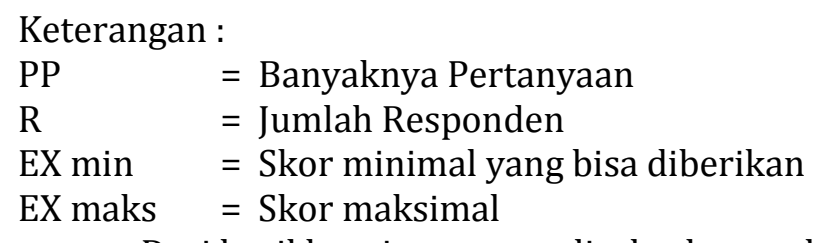

Dari hasil kuesioner yang disebarkan maka dapat diketahui :

$\begin{aligned} \mathrm{PP} & =10 \\ \mathrm{R} & =35 \\ \text { EX min } & =1 \\ \text { EX maks } & =5 \\ \text { IK maks } & =35 \times 10 \times 5 \\ & =1.750 \\ \text { IK min } & =35 \times 10 \times 1 \\ \text { Interval } & =350 \\ & =1.750-350 \\ & =1.400 / 5 \\ & =280\end{aligned}$

Sehingga skala tingkat kepuasan pelanggan dapat dikategorikan sebagai berikut :

Keterangan:
a) $350-630=$ Sangat Tidak Puas
b) $631-911=$ Tidak Puas
c) $912-1.192=$ Cukup Puas
d) $1.193-1.473=$ Puas
e) $1.474-1.754$ = Sangat Puas

Dari hasil penyebaran kuisioner kepada Pasien Rumah Sakit Bhayangkara POLDA Bengkulu dapat dilihat pada tabel 4 :

Tabel 4: Persepsi pelanggan tentang kepuasan pelanggan Rumah Sakit Bhayangkara POLDA Bengkulu

\begin{tabular}{|c|c|c|c|c|c|c|c|}
\hline \multirow{2}{*}{ No } & \multirow{2}{*}{ Pertanyaan } & \multicolumn{5}{|c|}{ Skor } & \multirow{2}{*}{$\underset{\text { Jumla }}{\text { Juml }}$} \\
\hline & & SP & $\mathbf{P}$ & $\mathbf{C P}$ & TP & STP & \\
\hline 1 & Respon jawaban telepon & 27 & 8 & 0 & 0 & 0 & 167 \\
\hline 2 & $\begin{array}{l}\text { Tatakrama staff pada Rumah Sakit Bhayangkara } \\
\text { POLDA Bengkulu }\end{array}$ & 32 & 3 & 0 & 0 & 0 & 172 \\
\hline 3 & Waktu tunggu pelayanan melalui telepon & 28 & 7 & 0 & 0 & 0 & 168 \\
\hline 4 & Penyambungan telepon pada orang yang tepat & 27 & 8 & 0 & 0 & 0 & 167 \\
\hline 5 & $\begin{array}{l}\text { Pelayanan staff penerima telepon secara } \\
\text { keseluruhan }\end{array}$ & 8 & $\begin{array}{l}1 \\
2\end{array}$ & 8 & 7 & 0 & 126 \\
\hline 6 & Pelayanan dan penanganan keluhan pasien & 24 & 9 & 2 & 0 & 0 & 162 \\
\hline 7 & Waktu penyelesaian keluhan pasien & 21 & $\begin{array}{l}1 \\
4\end{array}$ & 0 & 0 & 0 & 161 \\
\hline 8 & Pemenuhan schedule yang telah disepakati & 24 & $\begin{array}{l}1 \\
1\end{array}$ & 0 & 0 & 0 & 164 \\
\hline 9 & $\begin{array}{l}\text { Penjelasan yang diberikan tenaga teknis di } \\
\text { lapangan }\end{array}$ & 21 & $\begin{array}{l}1 \\
3 \\
\end{array}$ & 1 & 0 & 0 & 160 \\
\hline 10 & $\begin{array}{l}\text { Keahlian tenaga teknis dalam menyelesaikan } \\
\text { problem dilapangan. }\end{array}$ & 24 & $\begin{array}{l}1 \\
0\end{array}$ & 1 & 0 & 0 & 163 \\
\hline \multicolumn{7}{|c|}{ Total } & 1.610 \\
\hline
\end{tabular}

Sumber : Hasil Penelitian, 2013

Diperoleh hasil indeks kepuasan karyawan sebesar 1.610. Sehingga, dari hasil ini menunjukkan bahwa pasien di Rumah Sakit Bhayangkara POLDA Bengkulu dapat 
dikategorikan sangat puas terhadap kinerja Rumah Sakit Bhayangkara POLDA Bengkulu . Pasien dikatakan sangat puas karena berada pada interval 1.474-1.754.

\section{Kinerja Perspektif Internal Bisnis}

1. Jumlah Kunjungan Rawat Jalan Diambil dari Rekam Medik Rumah Sakit Bhayangkara POLDA Bengkulu

Tabel 5. Rata-rata Kunjungan Rawat Jalan perhari Rumah Sakit Bhayangkara POLDA Bengkulu selama tahu 2011-2012

\begin{tabular}{|l|c|c|c|}
\hline Indikator & $\mathbf{2 0 1 1}$ & $\mathbf{2 0 1 2}$ & Rata-Rata \\
\hline Rata-rata kunjungan rawat jalan perhari (RK) & 157 & 160 & 159 \\
\hline
\end{tabular}

Sumber : Rumah Sakit Bhayangkara POLDA Bengkulu, 2013

Berdasarkan tabel diatas, dapat dilihat bahwa dari tahun ke tahun rata-rata kunjungan rawat jalan selau meningkat. Kenaikan ini menunjukkan bahwa citra Rumah Sakit Bhayangkara POLDA Bengkulu_dari tahun ke tahun semakin menunjukkan peningkatan. Sehingga, semakin tahun rata-rata kunjungan pasien rawat jalan semakin meningkat.

2. Jumlah Kunjungan Rawat Inap

Indikator yang digunakan untuk mengukur kinerja bisnis internal ini adalah rasiorasio yang menunjukkan kualitas pelayanan suatu rumah sakit. Berikut ini adalah standar nilai rasio yang digunakan untuk mengukur perspektif bisnis internal ini berdasarkan Ditjen Bina Yanmed tahun 2005:

Tabel 6. Standar Ideal Rasio-rasio terkait dengan Pelayanan Rumah Sakit berdasarkan Ditjen Bina Yanmed

\begin{tabular}{|c|c|}
\hline Rasio & Standar Ideal \\
\hline BOR & $60-85 \%$ \\
\hline ALOS & $6-9$ Hari \\
\hline BTO & $40-50$ kali \\
\hline TOI & $1-3$ Hari \\
\hline GDR & Tidak Lebih dari 45 per 1000 pasien keluar \\
\hline NDR & Tidak Lebih dari 25 per 1000 pasien keluar \\
\hline
\end{tabular}

Sumber : Ditjen Bina Yamed, 2005

Tabel 7. Laporan Kinerja Rumah Sakit Bhayangkara POLDA Bengkulu selama tahu 2011-2012

\begin{tabular}{|l|c|c|}
\hline & $\mathbf{2 0 1 1}$ & $\mathbf{2 0 1 2}$ \\
\hline BOR & $72,00 \%$ & $\mathbf{7 7 , 0 0 \%}$ \\
\hline ALOS & 5 hari & 4 hari \\
\hline BTO & 55 kali & 60 kali \\
\hline TOI & 2 hari & 1 hari \\
\hline GDR & 37 orang & 41 orang \\
\hline NDR & 19 orang & 23 orang \\
\hline
\end{tabular}

Sumber : Bagian Rekam Medik Rumah Sakit Bhayangkara POLDA Bengkulu, 2013

\section{a. ALOS (Average Length Of Stay)}

ALOS dari Rumah Sakit Bhayangkara POLDA Bengkulu_tidak berada pada posisi yang yang ideal. ALOS ditahun 2011 adalah 5 hari, tahun 2012 menjadi 4 hari. Karena ALOS ini menunjukkan rata-rata lama rawat seorang pasien, maka dari data ini dapat disimpulkan bahwa rata-rata rawat inap pasien di Rumah Sakit Bhayangkara POLDA 
Bengkulu adalah selama 4,5 hari, yang tidak berada pada rentang ideal. Rumus mencari ALOS adalah :

$$
\text { ALOS }=\frac{\text { Jwmlah hari perawatam pasien kelwar }}{j \text { wmlah pasien kelwar ( hidwptmati })} \times 100 \%
$$

\section{b. BOR (Bed Occupancy Ratio)}

Dari data diatas, dapat disimpulkan bahwa kinerja Rumah Sakit Bhayangkara POLDA Bengkulu telah bagus untuk indikator BOR ini, hal ini terbukti dari masuknya kriteria ideal yang telah ditetapkan oleh Depkes RI yakni indikator ini antara 60- 85\%. Nilai BOR yang ideal tersebut juga mengindikasikan bahwa jumlah pasien yang dirawat tidak melebihi kapasitas tempat tidur yang tersedia pada Rumah Sakit Bhayangkara POLDA Bengkulu. Rumus mencari BOR adalah:

$$
\text { BOR }=\frac{\text { Jwmlah hari perawatan rumah salvit }}{\text { jumlah tempat tidur } x \text { jumlah hari dalam seming }} x 100 \%
$$

\section{c. TOI (Turn Over Internal)}

Dari hasil diatas dapat dilihat bahwa indikator TOI Rumah Sakit Bhayangkara POLDA Bengkulu sudah baik. Kriteria ideal untuk TOI adalah 1-3 hari, dan Rumah Sakit Bhayangkara POLDA Bengkulu mampu mencapainya. Berdasarkan tabel diatas, nilai TOI ditahun 2011 sampai 2012 rata-rata hari tidak digunakannya tempat tidur adalah 1 hari. Rumus mencari TOI adalah:

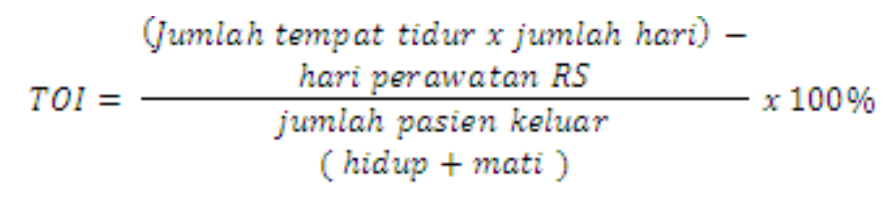

\section{d. BTO (Bed Turn Over Rate)}

Berdasarkan tabel diatas, nilai BTO Rumah Sakit Bhayangkara POLDA Bengkulu tidak berada dalam golongan yang ideal. Sesuai dengan kriteria Depkes nilai ideal BTO ini adalah antara 40 sampai 50 kali.

Apabila dilihat dari tahun ketahun indikator BTO ini selalu meningkat,pada tahun 2011 BTO Rumah Sakit Bhayangkara POLDA Bengkulu adalah 55 kali pada tahun 2011 ditahun 2012 adalah 60 kali. Hal ini menunjukkan bahwa tingkat efisiensi rata- rata pemakaian tempat tidur dalam setahun masih belum baik. Secara tidak langsung tingginya nilai BTO ini dipengaruhi oleh semakin banyaknya jumlah pasien rawat inap Rumah Sakit Bhayangkara POLDA Bengkulu, sebab rasio ini membandingkan antara jumlah pasien keluar (hidup dan mati) dibandingkan dengan jumlah tempat tidur, karena semakin banyaknya jumlah pasien maka semakin banyak juga jumlah pasien yang keluar. Selain itu, tidak idealnya indikator ini juga disebabkan karena jumlah tempat tidur di Rumah Sakit Bhayangkara POLDA Bengkulu tidak mengalami penambahan dari tahun 2011 sampai 2012, tetapi meskipun begitu untuk saat ini Rumah Sakit Bhayangkara POLDA Bengkulu telah mengupayakan perbaikan dengan melakukan penambahan jumlah tempat tidur. Rumus untuk mencari BTO adalah :

$$
\text { BTO }=\frac{\text { Jumlah pasien keluar (hidup + mati) }}{\text { jumlah tempat tidur }} \times 100 \%
$$

\section{e. GDR (Gross Death Rate)}

GDR Rumah Sakit Bhayangkara POLDA Bengkulu secara umum sudah bagus, karena jumlah tersebut masih berada didalam standar yang ideal untuk GDR.Berdasarkan Depkes RI. Dimana angka Rumah Sakit Bhayangkara POLDA Bengkulu dari tahun 2011 sampai tahun 2012 berada pada angka kurang dari 45 penderita. 
Apabila melihat lebih lanjut pada tabel diatas, angka GDR pada RSUD Rumah Sakit Bhayangkara POLDA Bengkulu semakin naik dari tahun ketahun, yakni ditahun 2011 jumlah pasien meninggal 37 orang dan ditahun 2012 menjadi 41 orang.

Apabila melihat pada indikator ideal yang ditetapkan Depkes RI, nilai NDR pada Rumah Sakit Bhayangkara POLDA Bengkulu sudah ideal. Karena, nilai ideal untuk NDR adalah tidak lebih dari 25 penderita untuk setiap 1000 penderita.

Tetapi, apabila dilihat lebih lanjut, NDR di Rumah Sakit Bhayangkara POLDA Bengkulu ini dari tahun ketahun terus mengalami kenaikan. Ditahun 2011 sebanyak 19 orang dan ditahun 2011 meningkat menjadi 23 orang.Secara umum, penyebab utama tingginya NDR ini hampir sama seperti kasus untuk GDR yaitu pelayanan perawatan yang masih kurang memenuhi standar sehingga angka kematian tinggi. Selain itu juga disebabkan dari jumlah pasien dari tahun ketahun selalu bertambah banyak. Sehingga peluang untuk terjadi kematian cukup tinggi, tetapi, angka NDR ini lebih dapat mencerminkan kualitas pelayanan di Rumah Sakit Bhayangkara POLDA Bengkulu, sebab angka GDR ini didasarkan atas jumlah kematian diatas 48 jam, tidak seperti GDR yang mendasarkan jumlah kematian keseluruhan yang seringkali menimbulkan bias, sebab banyak diantaranya sebelum pelayanan maksimal diberikan bagi pasien dengan sakit keras yang baru dilarikan ke rumah sakit tetapi sebelum 48 jam pasien telah meninggal. Rumus untuk mencari GDR adalah :

$$
\text { GDR }=\frac{\text { Jumlah pasien mati }>48 \mathrm{jam}}{\text { Jumlah pasien keluar (hidup }+ \text { mati) seming gu }} \times 100 \%
$$

\section{Kinerja Perspektif Pembelajaran dan Pertumbuhan}

a. Kepuasan Karyawan

Dari data yang telah dikumpulkan dari hasil kuisioner kepada 15 orang karyawan Rumah Sakit Bhayangkara POLDA Bengkulu dapat ditentukan interval kepuasan karyawan Rumah Sakit Bhayangkara POLDA Bengkulu yang digunakan untuk mengetahui tingkat kepuasan karyawan.

Penulis memberikan pertanyaan kepada karyawan dalam bentuk kuesioner dan pengukuran dalam menentukan jawaban pada penelitian ini yaitu menggunakan analisis skala likert (Singarimbun, 2005:111). Adapun alternatif jawaban kuesioner dan pemberian skor adalah sebagai berikut:

a) Jawaban sangat puas akan diberi skor 5

b) Jawaban puas akan diberi skor 4

c) Jawaban ragu-ragu akan diberi skor 3

d) Jawaban tidak puas akan diberi skor 2

e) Jawaban sangat tidak puas akan diberi skor 1

Penetapan tingkat kepuasan karyawan secara keseluruhan didasarkan pada skala yang digunakan untuk pengolahan data, yakni:

$$
\begin{aligned}
& \text { IK maks }=\mathrm{R} \times \mathrm{PP} \times \text { EX maks } \\
& \text { IK min }=\mathrm{R} \times \mathrm{PP} \times \mathrm{EX} \text { min } \\
& \text { Interval }=(\text { IK maks }- \text { IK min }) \\
& \text { Sugiyono } \\
& \text { (2002: 80) }
\end{aligned}
$$

$$
\begin{aligned}
& \text { Keterangan : } \\
& \mathrm{PP} \quad=\text { Banyaknya Pertanyaan } \\
& \mathrm{R} \quad=\text { Jumlah Responden } \\
& \mathrm{EX} \mathrm{min}=\text { Skor minimal yang bisa diberikan } \\
& \text { EX maks }
\end{aligned}
$$


Dari hasil kuesioner yang disebarkan maka dapat diketahui :

$$
\begin{aligned}
\mathrm{PP} & =10 \\
\mathrm{R} & =25 \\
\text { EX min } & =1 \\
\text { EX maks } & =5 \\
\mathrm{IK} \text { maks } & =25 \times 10 \times 5 \\
& =1.250 \\
\mathrm{IK} \text { min } & =25 \times 10 \times 1 \\
& =250 \\
\text { Interval } & =1.250-250 \\
& =1.000 / 5 \\
& =200
\end{aligned}
$$

Sehingga skala tingkat kepuasan pelanggan dapat dikategorikan sebagai berikut :

\begin{tabular}{|c|c|c|c|c|c|c|c|}
\hline \multirow{2}{*}{ No } & \multirow{2}{*}{ Pertanyaan } & \multicolumn{5}{|c|}{ Skor } & \multirow{2}{*}{ Jumlah } \\
\hline & & SP & $\mathbf{P}$ & $\mathbf{C P}$ & $\mathbf{T P}$ & STP & \\
\hline 1 & $\begin{array}{l}\text { Sistem kerja yang diterapkan Rumah } \\
\text { Sakit }\end{array}$ & 15 & 8 & 2 & 0 & 0 & 113 \\
\hline 2 & Sistem penggajian dan kenaikan gaji & 18 & 7 & 0 & 0 & 0 & 118 \\
\hline 3 & Sistem tunjangan dan fasilitas lainnya & 20 & 5 & 0 & 0 & 0 & 120 \\
\hline 4 & $\begin{array}{l}\text { Komunikasi yang baik antara pimpinan } \\
\text { dan staff }\end{array}$ & 17 & 7 & 1 & 0 & 0 & 116 \\
\hline 5 & $\begin{array}{l}\text { Komunikasi yang baik antara pimpinan } \\
\text { dan staff }\end{array}$ & 10 & 9 & 6 & 0 & 0 & 104 \\
\hline 6 & $\begin{array}{l}\text { Pemberian reward/penghargaan pada } \\
\text { karyawan }\end{array}$ & 13 & 5 & 4 & 2 & 1 & 102 \\
\hline 7 & $\begin{array}{l}\text { Pekerjaan sesuai dengan kemampuan } \\
\text { karyawan }\end{array}$ & 16 & 7 & 1 & 1 & 0 & 113 \\
\hline 8 & $\begin{array}{l}\text { Kepercayaan Rumah Sakit terhadap } \\
\text { karyawan }\end{array}$ & 15 & 10 & 0 & 0 & 0 & 115 \\
\hline 9 & $\begin{array}{l}\text { Tersedia data karyawan yang lengkap } \\
\text { dan akurat }\end{array}$ & 13 & 8 & 3 & 1 & 0 & 108 \\
\hline 10 & $\begin{array}{l}\text { Tersedia data pelanggan yang lengkap } \\
\text { dan akurat }\end{array}$ & 12 & 10 & 3 & 0 & 0 & 109 \\
\hline & Total & & & & & & 1.014 \\
\hline
\end{tabular}

Keterangan:
a. $250-450=$ Sangat Tidak Puas
b. $451-651=$ Tidak Puas
c. $652-852=$ Cukup Puas
d. $853-1.053=$ Puas
e. $1.054-1.254$ = Sangat Puas

Dari hasil penyebaran kuisioner kepada karyawan Rumah Sakit Bhayangkara POLDA Bengkulu dapat dilihat pada tabel 8 :

Tabel 8 : Persepsi karyawan tentang kepuasan karyawan Rumah Sakit Bhayangkara POLDA Bengkulu

Dari hasil penyebaran kuisioner kepada karyawan Rumah Sakit Bhayangkara POLDA Bengkulu, diperoleh hasil indeks kepuasan karyawan sebesar 1.014. Sehingga, dari hasil ini karyawan Rumah Sakit Bhayangkara POLDA Bengkulu dapat dikategorikan puas sebagai 
karyawan Rumah Sakit Bhayangkara POLDA Bengkulu. Karyawan merasa puas karena berada pada interval $853-1.053$.

b. Retensi Karyawan

Tabel 9. Nilai Retensi Karyawan Rumah Sakit Bhayangkara POLDA Bengkulu selama tahu 2011-2012

\begin{tabular}{|c|c|c|c|}
\hline Tahun & $\begin{array}{c}\text { Jumlah Karyawan } \\
\text { Keluar }\end{array}$ & $\begin{array}{c}\text { Jumlah Total } \\
\text { Karyawan }\end{array}$ & Retensi Karyawan \\
\hline 2011 & 20 & 347 & $5,76 \%$ \\
\hline 2012 & 13 & 363 & $3,58 \%$ \\
\hline
\end{tabular}

Sumber : Rumah Sakit Bhayangkara POLDA Bengkulu, 2013

Dari data tabel diatas, dapat dilihat bahwa persentase retensi karyawan dari tahun ketahun semakin menurun. Hal ini menunjukkan bahwa indikator retensi karyawan ini dari tahun 2011sampai tahun 2012 semakin baik. Ditahun 2011 tingkat retensi karyawan Rumah Sakit Bhayangkara POLDA Bengkulu berada pada tingkat 5,76\% dan menjadi 3,58\% di tahun 2012. Menurunnya indikator retensi karyawan ini dapat diartikan bahwa tingkat perputaran karyawan semakin baik.

\section{c. Produktivitas Karyawan}

Tabel 10. Produktivitas Karyawan Rumah Sakit Bhayangkara POLDA Bengkulu selama tahu 2011-2012

\begin{tabular}{|c|c|c|c|}
\hline Tahun & Jumlah Pendapatan & $\begin{array}{c}\text { Jumlah Total } \\
\text { Karyawan }\end{array}$ & $\begin{array}{c}\text { Produktivitas } \\
\text { Karyawan }\end{array}$ \\
\hline 2011 & Rp. $\quad 4.371 .043 .224$ & 347 & Rp. 41.415 .110 \\
\hline 2012 & $\begin{array}{ll}\text { Rp. } & 21.536 .865 .164\end{array}$ & 363 & Rp. 59.330.207 \\
\hline
\end{tabular}

Sumber : Rumah Sakit Bhayangkara POLDA Bengkulu, 2013

Dari tabel diatas dapat diketahui bahwa produktivitas karyawan dari tahun ketahun semakin menunjukkan peningkatan. Ditahun 2011, produktivitas karyawan Rumah Sakit Bhayangkara POLDA Bengkulu adalah Rp. 41.415 .110 pertahun artinya rata-rata satu orang karyawan dapat menghasilkan pendapatan untuk Rumah Sakit Bhayangkara POLDA Bengkulu sebesar Rp. 41.415.110 selama satu tahun. Dan terjadi peningkatan pada tahun 2012 sebesar Rp. 59.330.207. Dari data ini dapat dilihat bahwa semakin tahun, kinerja yang dihasilkan oleh karyawan semakin baik. Sehingga, pada akhirnya dapat memberikan kontribusi berupa pendapatan yang semakin tinggi bagi Rumah Sakit Bhayangkara POLDA Bengkulu

\section{Pembahasan}

Berdasarkan hasil penelitian yang telah dilakukan terhadap pengukuran kinerja Rumah Sakit Bhayangkara POLDA Bengkulu dengan menggunakan analisis balanced scorecard maka dilakukan pengukuran secara keseluruhan untuk mengetahui "kurang", "cukup", atau "baik" kinerja dari Rumah Sakit Bhayangkara POLDA Bengkulu tersebut.

Hasil penilaian kinerja manajemen dibawah ini merupakan hasil analisa dari data-data yang tersaji , berikut ini adalah hasil secara keseluruhan dari penelitian kinerja pada Rumah Sakit Bhayangkara POLDA Bengkulu seperti pada table 11. 
Tabel 11. Skor Penilian Balanced Scorecard Rumah Sakit Bhayangkara POLDA Bengkulu selama tahu 2011-2012

\begin{tabular}{|c|c|c|c|}
\hline \multicolumn{2}{|r|}{ Indikator } & \multirow[t]{2}{*}{ Kretiria } & \multirow[t]{2}{*}{ Skor } \\
\hline 1. & Kinerja Perspektif Keuangan & & \\
\hline & Rasio Ekonomi & Baik & 1 \\
\hline & Rasio Efisiensi & Baik & 1 \\
\hline & Rasio Efektivitas & Kurang & -1 \\
\hline \multirow[t]{2}{*}{2.} & Kinerja Perspektif Pelanggan & & \\
\hline & Kepuasan pelanggan & Baik & 1 \\
\hline \multirow[t]{9}{*}{3.} & Kinerja Perspektif Internal Bisnis & & \\
\hline & Jumlah Kunjungan Rawat Jalan & Baik & 1 \\
\hline & Jumlah Kunjungan Rawat Inap & & \\
\hline & - ALOS & Kurang & -1 \\
\hline & $-\mathrm{BOR}$ & Baik & 1 \\
\hline & - TOI & Baik & 1 \\
\hline & - BTO & Kurang & -1 \\
\hline & - GDR & Baik & 1 \\
\hline & - NDR & Baik & 1 \\
\hline \multirow[t]{4}{*}{4.} & Kinerja Perspektif Pembelajaran dan Pertumbuhan & & \\
\hline & Kepuasan Karyawan & Baik & 1 \\
\hline & Retensi Karyawan & Baik & 1 \\
\hline & Produktivitas Karyawan & Baik & 1 \\
\hline \multicolumn{2}{|c|}{$\begin{array}{l}\text { Total } \\
\text { Rata-Rata Skor }\end{array}$} & & $\begin{array}{c}8 \\
0,57\end{array}$ \\
\hline
\end{tabular}

Sumber : Data diolah peneliti, 2013

Total hasil bobot skor Rumah Sakit Bhayangkara POLDA Bengkulu adalah 10 dari 14 ukuran kinerja. Sehingga, rata-rata skor adalah $=8 / 14=0,57$. Setelah diperoleh rata-rata skor, langkah selanjutnya adalah membuat skala untuk menilai total skor tersebut, sehingga kinerja Rumah Sakit Bhayangkara POLDA Bengkulu dapat dikatakan "kurang", "cukup", dan "baik". Dengan menggunakan skala, maka dapat diketahui kinerja Rumah Sakit Bhayangkara POLDA Bengkulu. Berikut adalah gambar skala kinerja Rumah Sakit Bhayangkara POLDA Bengkulu .

\section{Gambar 2. Skala Penilaian Kinerja Penilian Balanced Scorecard Rumah Sakit Bhayangkara POLDA Bengkulu selama tahu 2011-2012}

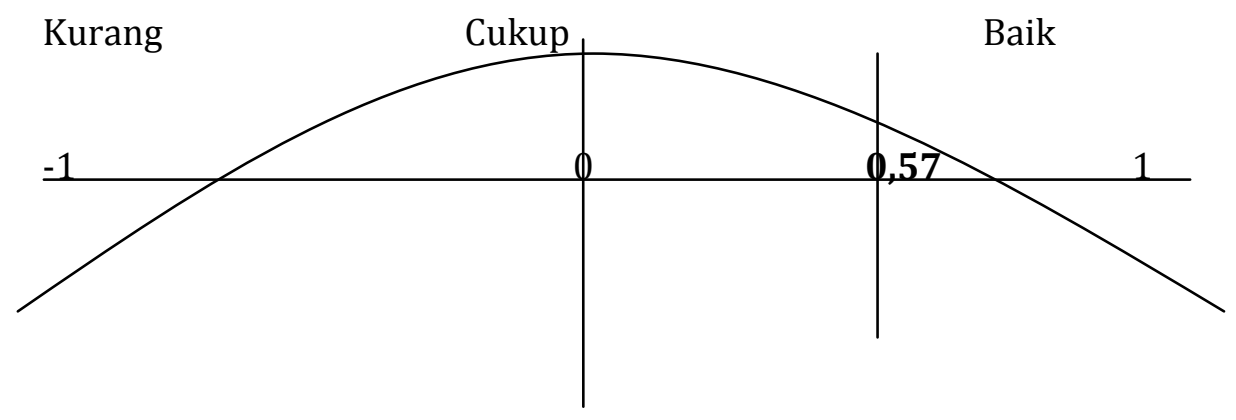

Setelah membuat skala. Selanjutnya adalah menentukan batas area "kurang", "cukup" dan "baik". Skalanya adalah sebagai berikut:

$$
\begin{array}{ll}
-1-0 & \text { Kurang } \\
>0-0,50 & \text { Cukup } \\
>0,51-1,00 & \text { Baik }
\end{array}
$$

Dengan demikian hasil pengukuran kinerja secara keseluruhan dari Rumah Sakit Bhayangkara POLDA Bengkulu terdapat pada daerah baik, dengan skor total 0,57. Artinya, Kinerja Rumah Sakit Bhayangkara POLDA Bengkulu sudah baik apabila diukur dengan pendekatan Balanced Scorecard. 


\section{Kesimpulan}

Berdasarkan data yang diperoleh dan analisis data yang telah dilakukan, dapat disimpulkan bahwa:

\section{Perspektif Keuangan}

Kinerja Rumah Sakit Bhayangkara POLDA Bengkulu dilihat dari perspektif keuangan dengan menggunakan instrumen Value For Money yang terdiri atas: rasio ekonomi, rasio efisiensi, rasio efektivitas. Dari perspektif ini secara umum Rumah Sakit Bhayangkara POLDA Bengkulu telah ekonomis artinya realisasi pengeluaran selalu lebih kecil bila dibandingkan dengan anggaran yang telah dibuat. Selain itu, kinerja keuangan Rumah Sakit Bhayangkara POLDA Bengkulu telah efisien, hal ini dapat dilihat bahwa telah tercapainya target pendapatan yang dibuat pada tahun 2011 dan 2012. Sedangkan, apabila dilihat dari rasio efisiensi, Rumah Sakit Bhayangkara POLDA Bengkulu masih belum efisien. Hal ini dikarenakan besarnya pengeluaran yang dilakukan untuk merealisasikan pendapatannya.

2. Perspektif Pelanggan

Kinerja Rumah Sakit Bhayangkara POLDA Bengkulu dilihat dari perspektif pelanggan dengan indikator kepuasan pelanggan. Pasien Rumah Sakit Bhayangkara POLDA Bengkulu telah merasa puas atas kinerja Rumah Sakit Bhayangkara POLDA Bengkulu sesuai dengan hasil kuisioner.

3. Perspektif Internal Bisnis

Kinerja Rumah Sakit Bhayangkara POLDA Bengkulu dilihat dari perspektif internal bisnis dengan indikator inovasi, Rata-rata Kunjungan (RK), ALOS, BOR, TOI, BTO, GDR, NDR. Untuk rata-rata kunjungan juga semakin banyak dari tahun ketahun. Untuk rasio pelayanan kesehatan secara umum sudah cukup baik. Hanya saja untuk untuk rasio ALOS dan BTO masih belum masuk dalam kriteria ideal yang ditetapkan oleh Ditjen Bina Yanmed. Sehingga rasio untuk ALOS dan BTO masih belum baik.

4. Perspektif Pembelajaran dan Pertumbuhan

Kinerja Rumah Sakit Bhayangkara POLDA Bengkulu dilihat dari perspektif pembelajaran dan pertumbuhan dengan indikator kepuasan Karyawan, retensi karyawan, dan produktivitas karyawan. Untuk perspektif pembelajaran dan pertumbuhan Rumah Sakit Bhayangkara POLDA Bengkulu sudah baik. Hal ini dapat dilihat dari hasil karyawannya yang puas apabila diukur dari keseluruhan atribut, tapi hanya merasa cukup puas untuk atribut gaji dan promosi kerja. Sedangkan untuk retensi karyawan dari tahun ketahun semakin menurun, hal ini menunjukkan bahwa Rumah Sakit Bhayangkara POLDA Bengkulu semakin mampu untuk mempertahankan karyawannya. Begitupula dengan produktivitas karyawan yang dari tahun 2010 sampai tahun 2012 selalu naik.

5. Dari hasil pengukuran kinerja Rumah Sakit Bhayangkara POLDA Bengkulu secara keseluruhan menunjukkan bahwa kinerja Rumah Sakit Bhayangkara POLDA Bengkulu sudah baik dilihat dari keempat persepektif tersebut, yakni perspektif keuangan, pelanggan, internal bisnis dan pembelajaran dan pertumbuhan.

\section{Saran}

1. Pihak Rumah Sakit Bhayangkara POLDA Bengkulu sebaiknya menggunakan balanced scorecard untuk mengevaluasi kinerjanya untuh tahun-tahun kedepan.

2. Rumah Sakit Bhayangkara POLDA Bengkulu harus lebih mempertimbangkan penggunaan dana anggaran belanja dengan seefisien mungkin, dan mengurangi pengeluaran yangbersifat pemborosan atau kurang memiliki manfaat.

3. Karyawan harus lebih diapresiasi agar lebih puas dalam bekerja, dengan meningkatkan gaji dan mempermudah promosi jabatan bagi karyawan yang berprestasi.

4. Rumah Sakit Bhayangkara POLDA Bengkulu sebaiknya melakukan tambahan tempat tidur, sebab dari tahun 2011 sampai 2012 menurut data yang diperoleh, jumlah tempat tidur tidak berubah. Sebab, jumlah tempat tidur ini juga penting dalam peningkatan kinerja rasio BOR 
(Bed Occupancy ratio), TOI (Turn Over Internal), BTO (Bed Turn Over Rate). Karena, penghitungan rasio tersebut menyertakan jumlah tempat tidur.

\section{DAFTAR PUSTAKA}

Andranik, Aldhila Yugha. 2008. Penerapan Balance Scorecard Sebagai Tolok Ukurpengukuran Kinerja Pada Rumah Sakit Umum Daerah Jendral Ahmad Yani Kota Metro Lampung. Skripsi. Jakarta: Perbanas Jakarta.

Anwar Prabu Magkunegara. 2005. Sumber daya Manusia Perusahaan, Remaja Rosda Karya; Bandung.

Arikunto, Suharsimi. 2002. Prosedur Penelitian, Suatu Pendekatan Praktek. PT. Rineka Cipta Jakarta.

Blocher, J. Edward, KungH. Chen, Tho,mas W. Lin. 2000. Manajemen Biaya. Terjemahan Dra. A. Susty Ambariani, M.Si, Akt., Salemba Empat. Jakarta.

Hasan, I.. 2004. Analisi Dana PenelitianDengan Statistik. Bumi Aksara, Jakarta.

Kaplan, Robert S. dan Norton, David P.. 2000. Balance Scorecard, Menerapkan Strategi menjadi Aksi. Terjemahan. Penerbit Erlangga, Jakarta.

Mardiasmo. 2002. Akuntansi Sektor Publik. Andi, Yogyakarta. 2002. Otonomi dan Manajemen Keuangan Daerah. Andi, Yogyakarta.

Mulyadi. 2001. Akuntansi Manajemen Konsep, Manfaat dan Rekayasa. Salemba Empat. Jakarta.

Nasution, S.. 2009. Metode Research (Penelitian Ilmiah). Bumi Aksara, Jakarta.

Sugiyono. 2002. Metode Penelitian Administrasi. CV. Alfabeta, Bandung.

Sulastri, Atik. 2003. Penerapan Balance Scorecard Sebagai Sistem Penilai Kinerja pada Rumah Sakit Islam Surakarta. Skripsi tidak dipublikasikan. Fakultas Ekonomi, Universitas Sebelas Maret, Surakarta.

Sunrto. 2005. Manajemen Karyawan. Amus, Yogyakarta.

Ulum . Ihyaul 2009. Intellecual Capital Konsep dan Kajian Empiris. Graha Ilmu, Yogyakarta.

Yuwono, Sony. 2002. Petunjuk Praktik PenyusunanBalaned Scoredcard Menuju Organisasi yang Berfokus pada Strategi. PT. Gramedia Pustaka Utama, Jakarta. 